\title{
Peynir Altı Suyu ve Zeytinyağı Atıklarının Tarımda Gübreleme Amaçlı Kullanılabilirliği
}

\author{
${ }^{*}$ Hilal AYHAN Haluk KULAZ \\ Yüzüncü Yıl Üniversitesi, Ziraat Fakültesi, Tarla Bitkileri Bölümü, Van \\ *Sorumlu yazar e-posta (Corresponding author e-mail): hilalayhan@yyu.edu.tr
}

\begin{abstract}
Öz
Organik maddenin ayrışmasını hızlandırarak toprak verimliliğini olumsuz etkileyen küresel ısınmanın olumsuz etkisini azaltmak, organik maddece fakir olan Türkiye topraklarının yapısını muhafaza etmek amacıyla organik maddeler kullanılmaya başlanmıştır. Toprağın fiziksel, kimyasal ve biyolojik yapısını iyileştiren organik madde kaynaklarının kısıtı ve pahalı olması, organik madde kaynağı olan tarıma dayalı endüstri atıklarının kullanılmasına yönelik çalışmaların artmasını sağlamıştır. Öte yandan nüfusun hızla artması ve artan nüfus ile birlikte gıda işleyen fabrikaların sayısının da artması gıda atık miktarlarının artmasına ve buna paralel olarak sınırlı olan su ve toprak kaynaklarının kirlenmesine neden olmaktadır. Atık yığınlarının oluşturduğu bu sorunlar, artık ve atık miktarıın azaltılmasına, değerlendirilmesine, değerlendirme verimliliğinin artıııımasına ve kaynakların etkin kullanımına yönelik çalışmaları hızlandırmışıı.Bu derlemede, çevreye atılığında ortamın oksijenini tükettiği için yaşamı olumsuz etkileyen ve kirliliğe yol açan ama gübreleme amacıyla kullanıldığında toprağa olumlu katkılarının olduğu belirtilen peynir altı suyu ve Türkiye açısından önemli bir çevre problemi oluşturan zeytinyağı atıkları karasu ve prinanın kompostlaştırılarak organik gübre olarak kullanılması hakkında genel bilgiler verilmektedir.
\end{abstract}

Anahtar Kelimeler: Peynir altı suyu, zeytinyağı atıkları, kompost, organik gübre

\section{Availability of Olive Mill Wastewater and Whey so as to Fertilization in Agriculture}

\begin{abstract}
The organic substances have come into use to decrease the negative effect of global warming which affects the soil productivity negatively by speeding up the decay of organic substances, to conserve the structure of soils of Turkey which are deficient in organic substances. The scarcity and expensiveness of the organic substances improving the physical, chemical and biologic structure of soil have caused the studies related to the usage of agriculture based industrial refuse which is a source of organic substance to increase. On the other hand; the increase in the population and along with it in the number of factories processing food cause the food refuse to increase and correspondingly cause the limited water and soil sources to be polluted. These problems posed by waste streams speed up the studies related with reducing, utilizing, and increasing the utilization efficiency of residue and refuse amounts and related with the effective use of sources. In this compilation, general information on composting and usage as fertilizer of whey, which affects life negatively and causes pollution when dropped in the environment because it consumes the oxygen but contributes to the soil when used for fertilization, and of olive mill wastewater and prina, which are posing an environmental problem for Turkey, is given.
\end{abstract}

Keywords: Whey, olive mill wastewater, prina, compost, organic fertilizer

\section{Giriş}

$\mathrm{K}$ aliteli bir toprak yapısı geliştirmek ve onu muhafaza etmek sürdürülebilir tarımın amaçları arasındadır. Sürdürülebilir tarıma duyulan ilgiden dolayı, toprağın fiziksel, kimyasal ve biyolojik özelliklerini teşvik etmek için, organik atıkların ilavesi gibi tarımsal uygulamalara ivme kazandırılmıştır (Sonnleitner et al. 2003a).
Toprağın fiziksel özelliklerinin iyileştirilmesi, toprak neminin artmasını, toprak strüktürünün düzenlenmesini ve erozyona karşı toprak dayanıklılığını sağlamaktadır (Ocak ve Demir 2012). Özellikle son yıllarda toprak yapısını güçlendirmek için bazı organik substratlara yoğun ilgi gösterilmeye başlanmıştır (Lynch and 
Bragg 1985; Tisdall et al. 1997; Sonnleitner et al. 2003b). Nitekim endüstriyel ülkelerde topraktaki besin döngüsünü muhafaza etmek ve atık maddeleri organik madde olarak toprağa kazandırmak yönünde yoğun çalışmalar yürütülmektedir (Kirchmann and Ryan 2004).

Bu derlemede, zengin sütçülük artığı içerdiği mineral maddeler ve süt şekeri (laktoz) ile protein ve yağ gibi inorganik maddeler nedeniyle akarsulara, göllere ve hatta denizlere atıldığında, çevrede ortamın oksijenini tükettiği için yaşamı olumsuz etkileyen ve çevre kirlenmesine yol açan (Konar ve Arıoğlu 1987) ama çeşitli araştırıcılar tarafından (Ocak ve Demir 2012) bitki besin maddesi olarak bir değerinin bulunduğu ve özellikle gübreleme amacıyla kullanıldığında toprağa olumlu katkılarının olduğu belirtilen peynir altı suyunun kullanım olanakları irdelenmiştir.

Ayrıca çevreyi kirletmeden arıtımı ve bertarafı zeytinyağı üreticisi diğer ülkeler gibi Türkiye açısından da önemli bir çevre problemi oluşturan (Başkan 2010), içerisindeki yüksek fenolik maddeler ve fitotoksik etkilerden dolayı tarım alanlarında çok büyük problemler meydana getirmekte olan ama kompostlaştırma işlemi ile herhangi bir fitotoksik etkisi olmaksızın, organik gübre olarak kullanılmasına olanak sağlanan, (Monteoliva-Sacnhez et al. 1996) karasuyu ve prinanın tarım alanlarında gübreleme amaçlı kullanılma olanakları araştıııımıştır.

\section{Peynir Altı Suyu (PAS)}

Süt teknolojisinin en önemli yan ürünlerinden biri olan peynir altı suyunun (peynir altı suyunun genelde üç tipi mevcut: tatlı, ekşi, kazein) büyük bir kısmı ekşi peynir altı suyu atık ürünü olduğu bildirilmiştir (Pesta et al. 2006). Genel olarak sütün peynire işlenmesi sonucunda arta kalan sarımtırak-yeşil renkli sıvıya peynir suyu ya da peynir altı suyu denir. Diğer bir deyimle peynir yapımı sırasında kazeinin ve yağın pıhtı halinde ayrılmasından sonra serbest kalan sıvı peynir altı suyudur Peynir altı suyunun özellikleri ve bileşimi peynir üretim teknolojisi ve peynir üretiminde kullanılan sütün kalitesine bağlı olarak değişmektedir.Peynir altı suyunun bileşimi Çizelge 1'de verilmiştir (Dinçoğlu ve Ardıç 2012).

Uzun yıllardan beri bütün dünyada süt endüstrisinin karşı karşıya olduğu hemen hemen en önemli problemlerden biridir. Herhangi bir işlem görmeden çevreye atılan PAS, çok yüksek oranlarda organik madde içeriği nedeniyle çevre kirliligine neden oldugu gibi, içerdiği yüksek değerli besin unsurlarının da kaybına yol açmaktadır (Bakırcı ve Kavaz 2006).

Süt endüstrisi, yüksek oranda organik madde içeren, biyolojik oksijen ihtiyacı (BOI) ve kimyasal oksijen intiyacı (KOI) konsantrasyonları yüksek, kuvvetli karakterde atıksular üretmektedir. Atıksudaki yüksek organik yüke neden olan maddeler ise sütten kaynaklanan karbonhidratlar, proteinler ve yağlardır (Demirel ve ark. 2005). Bu maddeler nedeniyle akarsulara, göllere ve hatta denizlere atıldığında, çevrede ortamın oksijenini tükettiği için yaşamı olumsuz etkilemekte ve çevre kirlenmesine yol açmaktadır (Konar ve Arıoğlu, 1987). Peynir işlemede ortalama bir değerle her $100 \mathrm{~kg}$ sütün 85 kg'ı peynir altı suyuna çevrilir (Demirci ve Arıcı 1989). Dünyada yılda üretilen peynir altı suyu miktarı yaklaşık 85 milyon tondur (Mann 1986).

Biyolojik oksijen intiyacı kirli sulardaki organik maddeleri parçalamak için mikroorganizmalar tarafından kullanılan oksijen miktarını gösterir. Bir insanın günlük atıklarının parçalanabilmesi için bu değerin $60 \mathrm{~g} / \mathrm{l}, 1$ litre peynir suyu için ise bu değerin $40 \mathrm{~g} / \mathrm{l}$ olduğu saptanmıştır (Metin, 1983).Bir başka ifade ile peynir altı suyunun biyolojik oksijen ihtiyacı 39000-48000 ppm arasındadır. İçermiş olduğu organik maddeler esas kirlenme kaynağıdırlar. Bu organik maddeler sudaki erimiş oksijeni tükettiğinden, suda yaşayan canlılar, özellikle balıklar kendi yaşamları için gerekli oksijeni bulamaz ve yüksek

Çizelge 1. Peynir Altı Suyunun Bileşimi (g/L)

Table 1. Components of whey $(\mathrm{g} / \mathrm{L})$

\begin{tabular}{lcc}
\hline Bileşen & Tatıı Peynir Altı Suyu & Ekşi Peynir Altı Suyu \\
\hline Toplam Kuru Madde & $63.0-70.0$ & $63.0-70.0$ \\
Laktoz & $46.0-52.0$ & $44.0-46.0$ \\
Protein & $6.0-10.0$ & $6.0-8.0$ \\
Yağ & $3.0-3.5$ & $2.0-2.5$ \\
Kalsiyum & $0.4-0.6$ & $1.2-1.6$ \\
Fosfat & $1.0-3.0$ & $2.0-4.5$ \\
Laktat & 2.0 & 6.4 \\
Klorür & 1.1 & 1.1 \\
\hline
\end{tabular}


olmasına bağlı olarak ölmeye başlarlar. Buna karşılık toksikasyonlara neden olan bazı alg ve zehirli bitki türlerinin gelişmesi kolaylaşır. Bu durumu bir örnekle açıklayacak olursak günde 10 ton sütü peynire işleyen ve 8 ton peynir suyunu değerlendirmeden döken bir işletme, 8 bin nüfuslu bir kentin yaptığı kadar çevre kirlenmesine yol açmaktadır (Dinçoğlu ve Ardıç 2012).

Sürdürülebilir su yönetiminde nehir kirliliği üzerine yapılan bir çalışmada, Sakarya nehrinde yer alan süt ve süt mamülleri üreten bir fabrikanın en önemli kirlilik etkeninin, atık suya karışan peynir altı suyu olduğu bildirilmiştir (Gümrükçüoğlu ve Baştürk 2007).

Çevre sorunlarına ve doğanın korunmasına bilinçli olarak eğilen ve süt endüstrisi gelişmiş olan ülkelerde peynir altı suyundan çok daha fazla sayıda ürün (ilaç sanayi, etil alkol üretimi, yem sanayi, laktoz üretimi v.s.) eldesinde yararlanılmakta bunun yanı sıra peynir altı suyunun bitki besin maddesi olarak da bir değerinin bulunduğu ve özellikle gübreleme amacıyla kullanıldığında toprağa olumlu katkılarının olduğu çeşitli araştırıcılar tarafından ifade edilmektedir (Ocak ve Demir 2012).

A.B.D.'de yapılan bir çalışmada tarlaya atılan her 3 ton peynir altı suyunun bitkiye sağladığı besin maddeleri açısından 1 ton çiftlik gübresine eşdeğer olduğu hesaplanmış ve bu uygulamanın ekonomik olmakla birlikte toprağın yapısını da olumlu yönde etkilediği ifade edilmiştir (Ryder 1980).

Yapılan bir başka çalışmada tarlaya veya meraya verilen 1 ton peynir suyunun, toprağa 1.5 $\mathrm{kg} \mathrm{N}, 0.4 \mathrm{~kg} P$ ve $1.5 \mathrm{~kg}$ K'nın yanı sıra az miktarlarda da $\mathrm{Na}, \mathrm{Ca}, \mathrm{Mg}$, ve $\mathrm{Cl}$ sağladığını ve dönüme 25 ton'a kadar peynir altı suyunun rahatlıkla kullanılabileceğini bildirilmiştir (Gillies 1974).

Polonya' da yapılan bir araştırmada hektara 1000-1500 m3 peynir altı suyunun püskürtülmesi veya bitkilerin $3000-7000 \mathrm{~m}^{3}$ dozunda sulanması ile üründe önemli artışların olduğu saptanmıştır (Sienkiewicz and Riedel 1990). Toprağa peynir altı suyu uygulamasının toprağın porozitesini artırmasının yanı sıra mısır bitkisinde ürün artışlarını da teşvik ettiğini ortaya koyulmuştur (Watson 1978). Yapılan başka bir araştırmada ise, 1 hektara verilen 4.5 ton peynir altı suyu ile toprağa hektara $68 \mathrm{~kg} \mathrm{~N}, 30 \mathrm{~kg} \mathrm{P}, 70 \mathrm{~kg} \mathrm{~K}, 50 \mathrm{~kg}$ $\mathrm{S}, 53 \mathrm{~kg} \mathrm{Ca}, 20 \mathrm{~kg}$ Na ve $5 \mathrm{~kg} \mathrm{Mg}$ 'nin ilave olduğu ortaya konulmuştur (Morris 1985).
Atık madde olarak bilinen ve besin değeri oldukça yüksek olan peynir altı suyunu ülkemiz koşullarında tarım arazilerinde değerlendirme alanlarının yaratımasının toprak yapısındaki mikroorganizma populasyonu (Arbuskülar Mikorhizal Fungus (AMF) ve Rhizobium spp.) üzerindeki olumlu etkileri de göz önünde tutulduğunda önemli bir zorunluluk olduğu görülmektedir. Ancak bu uygulamalar sırasında dikkat edilmesi gereken en önemli noktanın peynir altı suyunun gerekli ve yeterli miktarlarda kullanılması gerektiği, aşıı miktarda kullanımın toprak yapısında bulunan mikroorganizma populasyonu üzerinde olumsuz etkilerde bulunabileceğinden gerekli miktarın üstüne çıkılmaması gerekmektedir (Özrenk ve ark. 2003).

\section{Zeytinyağı Atıkları}

Pirina, zeytinlerin mekanik olarak yağa işlenmesinden sonra arta kalan katı alt üründür. 100 kg zeytinden ortalama 15-22 kg zeytinyağı, $35-45 \mathrm{~kg}$ pirina ve $100 \mathrm{~kg}$ pirinadan ortalama 6$7.5 \mathrm{~kg}$ pirina yağı, $60-70 \mathrm{~kg}$ kuru pirina elde edilmektedir (Öcal 2005). Karasu ise zeytin meyvesinin \%45-50'sini oluşturmaktadır. Zeytinin işlenmesi sırasında yaklaşık 0.4-0.5 $\mathrm{m}^{3}{ }^{\prime} \mathrm{e}$ karşıı Iık 1 ton karasu çıkmakta, özellikle, 3 fazlı sistemlerde bu birebire denk gelmektedir. Yani 1 ton zeytinyağına karşılık 1 ton karasu çıkmaktadır (Göçmez 2013). Karasuyun bileşimi, uygulanan üretim teknolojisine, üretim miktarına ve kullanılan zeytin hammaddesine bağlı olarak değişmektedir (Öcal 2005).

Karasu, içerisindeki yüksek fenolik maddeler ve fitotoksik etkilerden dolayı tarım alanlarında çok büyük problemler meydana getirmektedir. Karasu yüksek fenolik içeriklerinden dolayı su kaynaklarının hızlı bir şekilde kirlenmesine sebep olduğundan, bu etkinin ortadan kaldırıması için son yıllarda bazı yasal düzenlemeler yapılmıştır. $\mathrm{Bu}$ düzenlemelerde lagünlerde buharlaştırma yöntemi önemli yer tutmaktadır (Göçmez 2013).

Çok yüksek bir organik kirlilik yüküne sahip olan karasuyun (biyokimyasal oksijen ihtiyacı 70$100 \mathrm{~g} / \mathrm{l}$, kimyasal oksijen intiyacı 100-130 g/l) sucul ortamlara (akarsu - göl - deniz) ve araziye gelişi güzel bırakılması çok önemli çevre sorunlarına neden olmaktadır (Şengül ve Oktay 2000).

Kompost hazırlamada kullanılan, koyu kırmızı renkli sıvı olan karasu toplam katı madde miktarı yüksek,organik maddesi çok yüksek, pH'sı düşük, azot, potasyum, fosfor ve 
Çizelge 2. Eskişehir ESOGÜ Ziraat Fakültesi Sarıcakaya Zeytinyağı Fabrikası (İki Fazlı) ve İznik Zeytinyağı Fabrikası (Üç Fazlı) Atıklarında Analiz Sonuçları

Table 2. Waste analysis of Eskişehir ESOGÜ Faculty of Agriculture Sarıcakaya Olive Mill (two-phase) and Iznik Olive Mill (three-phase)

\begin{tabular}{lccc}
\hline Özellikler & Birimi & İki fazlı Zeytin Yağı Atığı & Üç fazlı Zeytin Yağı Atığı \\
\hline EC & $(\mu \mathrm{S} / \mathrm{cm})$ & 7.32 & 8.98 \\
Kuru Madde & $\%$ & 29.00 & 26.60 \\
Organik Madde & $\%$ & 97.50 & 96.00 \\
Humik+Fulvik Asit & $\%$ & 27.10 & 59.20 \\
$\mathrm{~N}$ & $\%$ & 0.53 & 0.51 \\
$\mathrm{C}$ & $\%$ & 55.10 & 54.60 \\
$\mathrm{~K}$ & $\%$ & 1.34 & 2.21 \\
$\mathrm{Ca}$ & $\%$ & 0.11 & 0.21 \\
$\mathrm{P}$ & $\%$ & 0.14 & 0.34 \\
$\mathrm{~S}$ & $\%$ & 0.093 & 0.15 \\
$\mathrm{Mg}$ & $\%$ & 0.092 & 0.13 \\
$\mathrm{Na}$ & $\%$ & 0.021 & 0.018 \\
$\mathrm{Fe}$ & 198.00 & 72.80 \\
$\mathrm{~B}$ & $\mathrm{ppm}$ & 18.80 & 55.20 \\
$\mathrm{Mn}$ & $\mathrm{ppm}$ & 9.85 & 17.50 \\
$\mathrm{Zn}$ & $\mathrm{ppm}$ & 8.14 & 22.60 \\
$\mathrm{Cu}$ & $\mathrm{ppm}$ & 8.28 & 8.80 \\
$\mathrm{Mo}$ & $\mathrm{ppm}$ & 0.06 & 0.13 \\
$\mathrm{Cd}$ & $\mathrm{ppm}$ & 0.03 & 0.04 \\
$\mathrm{Cr}$ & $\mathrm{ppm}$ & 0.83 & 0.45 \\
$\mathrm{Ni}$ & $\mathrm{ppm}$ & 2.21 & 0.75 \\
$\mathrm{~Pb}$ & $\mathrm{ppm}$ & 0.05 & 0.25 \\
\hline
\end{tabular}

magnezyum içeriği yüksek tamamı organik materyal olup topraklara organik madde ve besin maddesi kazancı sağlaması (Püskülcü ve ark., 1995), kompostlaştırma işleminin, karasuyun herhangi bir fitotoksik etkisi olmaksızın, organik gübre olarak kullanılmasını sağlamıştır (Monteoliva-Sanchez et al. 1996).

Zeytinyağı üretiminde Avrupa ülkelerinden sadece Yunanistan ve Türkiye'de 3 fazlı sistem uygulanmaktadır. İspanya, Tunus ve Cezayir'de ise 2 fazlı sistemler kullanılmaktadır. 2 fazlı sistemde genelde pirina ve karasu karışık olarak çıkmakta, çıkan karasu miktarı azalmaktadır (Göçmez 2013). Çizelge 2'de iki ve üç fazlı zeytinyağı atıklarının bileşimi verilmiştir (Oruç 2012).

Sıcak iklim çimlerinden Cynodon dactylon (L.) Pers. (Bermuda çimi), Stenotaphrum secundatum (yengeçotu) ve sıcak iklim çimlerinden farklı olarak Ophiopogon japonicum (karaçim) tamamı kum, 1/2 kum + prina, tamamı prina olacak şekilde 3 farklı ortamda yetiştirilen bir çalışma sonunda, prinanın değişik bitki yetiştirme ortamlarında gübre olarak kullanım olanaklarının incelenmesi gerektiği bildirilmiştir (Öcal 2005).
Çeşitli kompost uygulamaları yapılan bir çalışmada saman ve talaş karasu ile ıslatılarak kompostlaştırmış ve karasu uygulamaları kompostların organik madde ve $\% \mathrm{~N}, \mathrm{P}, \mathrm{K}$ içerikleriğini ayrıca $\mathrm{Ca}, \mathrm{Mg}, \mathrm{Fe}, \mathrm{Zn}, \mathrm{Mn}, \mathrm{Cu}$ değerlerinin artırdığını, özellikle saman talaş gibi materyallerden kompost hazırlanırken besin değeri arttırmak için karasu,suyun yerine ıslatma materyali olarak kullanılabileceği belirlenmiştir (Çivrilli ve ark. 2008).

Başka bir çalışmada zeytin pirinası, C/N oranını ayarlamak için değişik organik düzenleyiciler ilave edilerek kompost bileşimi, kompostlama süresince incelenmiş, çalışma sonucunda; yüksek çimlenme indeksi değerleri $\% 80-88$, humifikasyon oranı $26.5-29.6$ ve yüksek organik madde içeriği $872-914 \mathrm{~g} \mathrm{~kg}^{-1}$ bulunmuş, tarımsal amaçlar için uygun, toksisite içermeyen, $\mathrm{N}$ ve $\mathrm{K}$ yönünden zengin organik gübre elde edilmiştir (Soyergin ve ark. 2005).

Karasudan elde edilen karasu kekinin vermikompost üretiminde kullanılması olanağı üzerine yapılan bir çalışmada $\% 20$ ve $\% 40$ karasu keki kullanılan ortamda kokon sayısı ile solucanların sayısı ve ortalama solucan ağırlığı arttığı, oluşan vermikompostun bitki büyümesi üzerine etkileri konusunda ek çalışmalara intiyaç bulunduğu bildirilmiştir (Göçmez 2013). 
Arıtılmış ve arıtılmamış zeytinyağı kara suyu ile domates, bakla, nohut, buğday ve arpa bitkilerinde çimlenme, bitki büyümesi ve toprak verimliliği üzerine yapılan çalışmada, arıtılmış zeytinyağı karasuyu ile yapılan sulamanın, su ile yapılan sulamaya göre daha iyi etkilediği, arıtılmamış zeytinyağı karasuyunun ise ters etki gösterdiği sonucuna ulaşılmıştır (Mekki et al. 2005).

Zeytinyağı karasuyu ve kümes gübresi ile hazırlanan kompostun sığır gübresine kıyasla hektara daha yüksek ton patates elde ettiği, zeytinyağı karasuyunun $(\mathrm{pH}$, elektiriksel iletkenlik, fenoller) negatif etkisinin olmadığı ve klasik gübreye alternatif, ekolojik gübre olarak umut verici olduğu sonucu yapılan başka bir çalışmada elde edilmiştir (Hachıcha et al. 2006).

Karasuyun lagünlerde bekletilip buharlaştırılması ve dibe çöken çamurun kurutulmasıyla elde edilen zeytin tortusunun ağaç başına $40 \mathrm{~kg}$ ve $80 \mathrm{~kg}$ olarak uygulandığı araştırma sonuçlarına göre 80 kg.lık uygulamada ürünü arttırıcı önemli sonuçlar elde edildiği ayrıca yaprak örneklerinde azot ve potasyum seviyelerinde artış olduğu kaydedilmiştir (Püskülcü ve ark. 1995).

\section{Sonuç}

Evsel atık su ile karşılaştırıldığında ortalama 400 kat daha fazla kimyasal oksijen intiyacı olan karasu, 1000 kişinin 1 günde oluşturduğu evsel atık suya eşdeğerde organik kirlilik içermektedir. Böylesine kirlilik yüküne sahip olmasına rağmen karasu, kompostlaştırma ile fitotoksik etkisi ortadan kaldırılarak kullanılabilmektedir. Günde 10 ton sütü peynire işleyen ve 8 ton peynir suyunu değerlendirmeden döken bir işletme, 8 bin nüfuslu bir kentin yaptığı kadar çevre kirlenmesine yol açmakta oysa bu zengin sütçülük artığı gübreleme amaçlı kullanıldığında toprak yapısındaki mikroorganizma popülasyonu üzerine olumlu etki oluşturmaktadır. Atıkların değerlendirilmesi, bertaraf edildiğinde kaybedilen enerjinin geri dönüşümünü sağladığından, bu konu üzerine daha ayrıntılı çalışmalar yapılarak, atıkların tüketilebilirlikleri arttırılabilmedir.

\section{Kaynaklar}

Bakırcı İ. ve Kavaz A., 2006. Peynir suyunun değerlendirme olanakları. Türkiye Gıda Kongresi; 24-26 Mayıs 2006, Bolu, s.77-80

Başkan E.A., 2010. Zeytinyağı işletmelerinin atıkları ve değerlendirme yolları. http://geka.org.tr/ yukleme/dosya/50922ee05dd057dd5408ad2 290aafa79.pdf, (ulaşım tarihi 14.07.2015)
Çivrilli S., Düzen E. ve Seferoğlu S., 2008. Zeytinyağı atığı olan karasuyun farklı materyallerle kompostlaştırılması ve diğer kompostlarla karşılaştırılması. I. Ulusal Zeytin Öğrenci Kongresi, 17-18 Mayıs 2008, Balıkesir, 115121

Demirci M. ve Arıcı M., 1989. Peyniraltı suyunun önemi. Hasad Dergisi, 5(4): 26-29

Demirel B., Yenigün O. ve Onay T.T., 2005. Süt endüstrisi atıksularının havasız arıtımı. ITÜ Dergisi, Su Kirlenmesi Kontrolü, 15(1-3): 3-16

Dinçoğlu H.A. ve Ardıç M., 2012. Peyniraltı suyunun beslenmemizdeki önemi ve kullanım olanakları. Harran Üniv. Vet. Fak. Derg., 1(1): 54-60

Gilles M.T., 1974. Whey Processing and Utilization. Noyes Data Crop., London.

Göçmez S., 2013. Karasu kekinin vermikompost üretiminde kullanım olanakları. Tema Vakfı Ulusal Vermikültür Çalıştayı, 16 Nisan 2013, Ankara, Bildiri Kitabı: 40-51

Gümrükçüoğlu M. ve Baştürk O., 2007. Coğrafi bilgi sistemleri kullanılarak sakarya nehri kirlilik yükünün belirlenmesi, TMMOB Harita ve Kadastro Mühendisleri Odası Ulusal Coğrafi Bilgi Sistemleri Kongresi KTÜ

Hachicha S., Chtourou M., Medhioub K. and Ammar E., 2006. Compost of poultry manure and olive mill wastes as an alternative fertilizer. Agron Sustain Dev., 26: 135-142

Kirchmann H. and Ryan M.H., 2004. Nutrients in organic farming- are there advantages from the exclusive use of organic manures and untreated minerals? In: Proc. of 4th International Crop Science Congress, 26 Sep-1 Oct 2004, Brisbane, Australia, pp. 1-16

Konar A. ve Arıoğlu H., 1987. Peynir suyunun soya üretiminde gübre olarak kullanılma olanakları üzerinde bir ön araştırma. Çukurova Üniv. Zir. Fak. Derg., 2(2): 14-18

Lynch J.M. and Bragg E., 1985. Microorganisms and soil aggregate stability. Adv. Soil Sci., 2: 287297.

Mann E., 1986. Whey utilisation. Dairy Industries International, 51(3): 11-12

Mekki A., Dhouıb A., Aloui F. and Sayadi S., 2005. Olive wastevater as an ecological fertiliser. Agron. Sustain Dev., 26: 61-67.

Metin M., 1983. Süt sanayiinde peynir suyunun değerᄀlendirilmesi. E. Ü. Müh. Fak. Gıda Müh. Bölümü Dergisi 1(1): 151-169

Monteoliva-Sanchez M., Inceti C., RamosCormenzana A., Paredes C., Roig A. and Cegarra J., 1996. The study of the aerobik 
bacterial microbiota and the biotoxity in various sample of olive mill wastewater (alpechin) during their composting process. Intenational Biodeterioration Biodegradation, 53: 211-214

Morris S., 1985. Whey, feed or fertilizer. Proceedings of the Ruakura Farmer's Conference, New Zealand, 37: 113-116.

Ocak E. ve Demir S., 2012. Toprak Verimliliği ve Bitki Gelişiminde Peyniraltı Suyu ve Arbusküler Mikorhizal Fungus (AMF)'un Önemi. YYÜ Tar. Bil. Dergisi, 22(1): 48-55

Oruç N., 2012. Zeytinyağı Fabrikası Atığı Karasu Ekolojik Kirlilik Yerine Toprak Düzenleyici Olabilir. SAÜ Fen Edebiyat Dergisi, 2012-1: 35-45

Öcal A., 2005. Zeytinyağı Atık Suyu Ve Pirinanın Bitki Yetiştirilmesinde Kullanım Olanaklarnın Anlaşılması. Yüksek Lisans Tezi, Çukurova Üniversitesi Fen Bilimleri Enstitüsü, Adana, $67 s$

Özrenk E., Demir S. ve Tüfenkçi Ş., 2003. Peyniraltı suyu uygulaması ile Glomus intraradices ve Rhizobium cicer inokulasyonlarının nohut bitkisinde bazı gelişim parametrelerine etkileri. Yüzüncü Yıl Üni., Ziraat Fak., Tarım Bilimleri Dergisi, 13(2): 127-132

Pesta G., Meyer-Pittroff R. and Russ W., 2006. Utilization of Whey. (Ed: V. Oreopoulou, W. Russ), Utilization of By-Products and Treatment of Waste in the Food Industry, Springer, 193-207

Püskülcü G., Dikmelik Ü. ve Akıllıoğlu A., 1995. Karasudan elde edilen tortunun zeytinde gübre olarak kullanılması üzerine bir araştırma. Tarım ve Köy İşleri Bakanlığı Tarımsal Kongre
Ryder D.N., 1980. Economic consideretions of whey processing. J. Society Dairy Technology, 33(2): 73-77

Sienkiewicz T. and Riedel C.L., 1990. Whey and Whey Utilization. Verlag Th. Mann, Gelsenkichen-Buer, Germany

Sonnleitner R., Lorbeer E. and Schinner F., 2003a. Monitoring of changes in physical and microbiological properties of a chernozem amended with different organic substrates. Plant Soil, 253: 391-402

Sonnleitner R., Lorbeer E. and Schinner F., 2003b. Effects of straw, vegetable oil, and whey on physical and microbiological properties of a chernozem. Appl. Soil Ecol., 22: 195-204

Soyergin S., Uysal E. ve Albayrak B., 2005. Zeytin kekinin (pirinanın) kompost yapım teknikleri ve organik gübre olarak kullanım olanaklarının araştırılması. Türkiye III. Organik Tarım Sempozyumu, 4-6 Kasım 2006, Yalova, s. 308-314

Şengül F. ve Oktav E., 2000. Zeytinyağı üretimi atıklarının arıtım alternatifleri. 1. Ulusal Çevre Kirliliği Kontrolü Sempozyumu Bildiri Kitabı. 46 Ekim 2000, Ankara, s. 224-231

Tisdall J.M., Smith S.E. and Rengasamy P., 1997. Aggregation of soil by fungal hyphae. Aust. J. Soil Res., 35: 55-60

Watson K.S., 1978. Continuing impact of the environmental area on the dairy industry. Proc. Whey Products Conference, Minneapolis-Minnesota, pp: 30-52 